\title{
An Analysis of the Relationship between Factors of Life Environment and Diseases in Agricultural Village
}

\author{
Kozo OKuda, M. D. \\ Director of the Noto Public General Hospital, Ishikawa Pref.
}

First of all, I would like to explain the present situation of agriculture in Japan for a moment, to let you understand the particular life environment of agricultural village.

More than thirty-five million of people in Japan are engaged in agriculture. That is about forty per cent of whole population in Japan.

Secondly, as for the type, it is typical intensive agriculture, which means a lot of labor and capitals are taken to get much yield from limited arable land.

The number of farm houses which have subsidiary business has been increasing after the Second War. For example, before the War, the twenty-five per cent of farm houses of all farm houses had subsidiary business, however, they increased to seventy-four per cent in 1963.

In generally, the economic status of farm houses is rather poor, in other words, farmers cannot get enough money for their living through agriculture. Consequently, the male farmers whether or not they have wives, show the tendency to leave their villages to find other jobs. Afterall the agriculture is left in the hands of house wives and old people. We call this type of agriculture as "House Wives' Agriculture" because of the important role of it is in the hands of house wives. Generally speaking, the labor in agriculture is rather heavy for females and for old people. (slide) Agriculture seems to be suitable work for strong males. But in Japan it is managed by females and old people as a matter of fact. Accordingly, the farmers who are left in their villages are suffering from over-working, which bring diseases so-called "Nofu-sho" (Farmer's Occupational Syndrome) such as stiff shoulder, lumbago, numbness of hands and legs, polyuria at night, short breathe insomnia, dizziness, and stiff stomach etc.

Between sixty and seventy percents of farmers in the villages are suffering from some diseases called "Farmer's Syndrome" which I already explained before.

Next slide shows first the general scenery of the village. Secondly, farmers are working in a damp rice field, up to around their waists, and you will also see women engaged in the rice-planting work bending their waist to such an extreme degree in the ordinary working conditions. Thirdly, the layout and building of the farmers' houses are rather simple even though the area is a cold and snowy part of the country. And yet women have to do their daily cooking 
in a dark and cold kitchen, and here again bending their waist extremely. Overworking and working conditions are the main cause to increase fatigue twice as much.

The next slide will show the statistics indicating the hours of sleeping and labor hours of the farming women, in the picture we can see eighty per cent of female farmers are suffering from "Farmer's Syndrome". "Lumbar Deformans" and symptom of "Osteo-arthrosis" will be found among the women whose ages are even between thirty and forty.

One way to solve the labor shortage in the farming areas, we can indicate an introduction and use of the machinery. It is a true fact that modern cultivation machines are introduced in farm villages which cause more fatigue both mentally

Fig. 1. Incidence of Farmer's Syndrome in Mechanized Farms \& Non-mechanized Farms

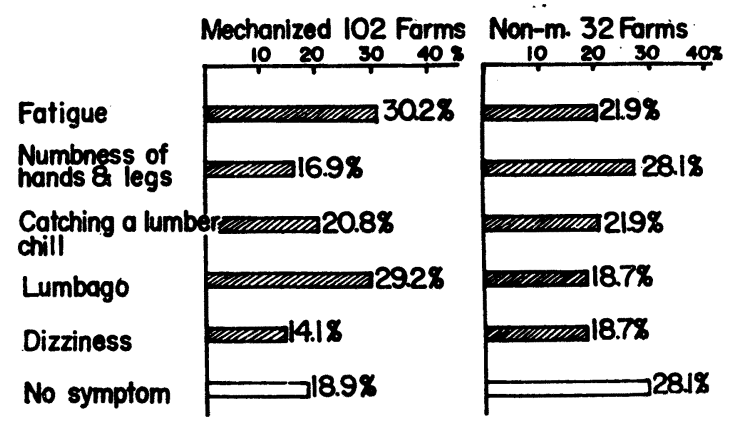

and physically. In this case the patient had been using the power cultivation machine and received external wound on his abdomen and his stomach came to rupture. (slide) The next case shows a patient who suffered severe injury combined with rupture of the kindney. (slide)

"Farmer's Syndrome" will due to the repetition of a working year after year, or chronic stress. In other words, it is a premedical state of the diseases caused by an accumulated fatigue, or "Premedical Symptom Complex (Syndrome)" which can be proved by "Stress Theory" of Dr. Selye.

I would like to make a full examination regarding "Farmer's Syndrome" by using a medical tool, electric dermometer. (slide) And it was found out that by means of "electric dermometer"'above mentioned symptoms, for example, stiff shoulder or lumbago could be examined electrophysiologically.

Report on nutrition of Japanese farm villages have been made by many doctors and researchers in our country. In general, it is an evident fact that a malnutrition is found among the Japanese farmers. A shortage of vitamins is so evident because of excessive intake of polished rice in farm villages. Amount of 
Table 1. Nutritive Analysis of Food Intake in the Farm Villages

Noto-District, Japan

\begin{tabular}{|c|c|c|c|}
\hline & $\begin{array}{l}\text { Standard amount } \\
\text { in Japan }\end{array}$ & $\begin{array}{l}\text { Average amount } \\
\text { in farm villages }\end{array}$ & $\begin{array}{l}\text { An example of the } \\
\text { minimum intake }\end{array}$ \\
\hline Calorie (Cal) & 2083 & 2205.5 & 2315.8 \\
\hline Protein (g) & 70.6 & 76.8 & 65.6 \\
\hline (g) & 29.2 & 21.16 & 12.9 \\
\hline Carbohydrates (g) & 381 & 317.2 & \\
\hline Calcium & 409 & 317.8 & 235 \\
\hline Salt & 13 & 45.92 & \\
\hline$A(I U)$ & 1452 & 1127.03 & 543 \\
\hline $\mathrm{B}_{1}(\mathrm{mg})$ & 1.03 & 2.15 & 0.6 \\
\hline Vitamins $B_{2}(\mathrm{mg})$ & 0.79 & 1.92 & 0.6 \\
\hline $\mathrm{C}(\mathrm{mg})$ & 79 & 83.62 & 25 \\
\hline$D(I U)$ & 400 & 29.48 & \\
\hline
\end{tabular}

Fig. 2. Analysis of Food in a Farmer's House

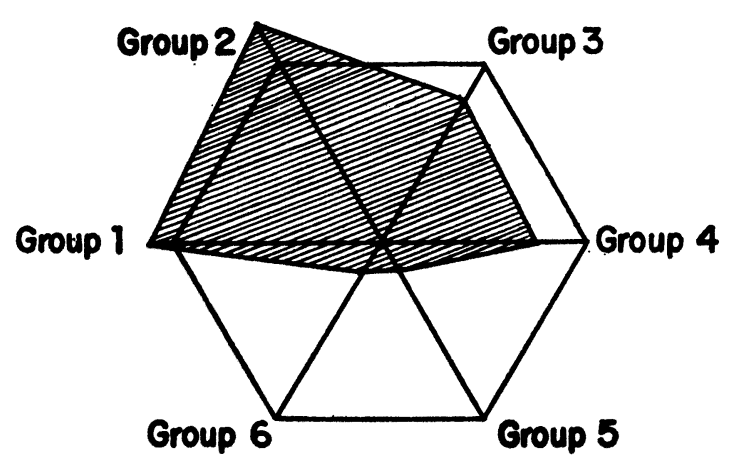

protein, fat, calcium taken are much low, vitamin $\mathrm{A}, \mathrm{B}$ and $\mathrm{C}$ are less than half the amount required.

This slide shows a high percentages of salt taken due to the necessity of hard working in this area. A high percentages of salt intake throughout the year will undoubtedly cause the high blood pressure and various diseases. (The slide shows the data concerning the result of salt taken.)

In farm villages, there can be found more cases of digestive diseases which are caused by poor diet and gluttony, especially the percentage of the cancer of stomach is very high. More than half of the cases of stomach cancer are the ones which are also too late to be given an operation. You can se $\odot$ the examples. 
Fig. 3. Intake of Salt

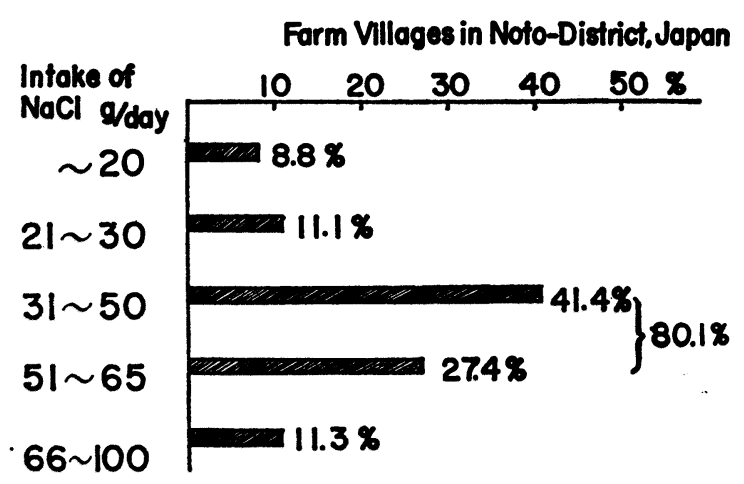

Fig. 4. Intake of Vitamin $B_{1}$

Farm Villages in Noto-District, Japan

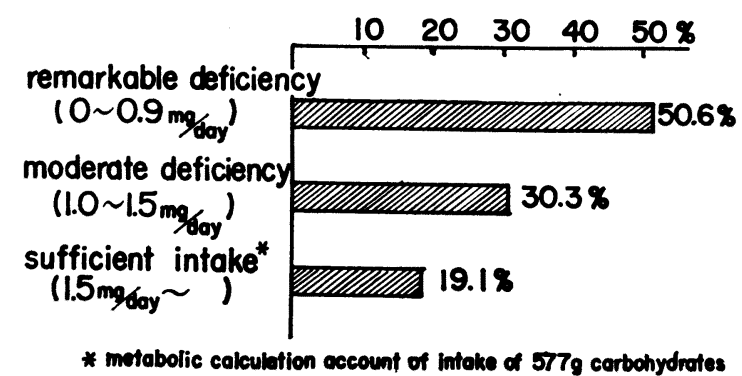

Table 2. Analysis of Food in a Farmer's House

Noto-District, Japan

\begin{tabular}{|c|c|c|c|c|}
\hline Foods & & & Standard amount in Japan & Average amou. in farm.-house \\
\hline Carbohydrates & (Group & 1) & $515 \mathrm{~g}$ & $557 \mathrm{~g}$ \\
\hline Protein & 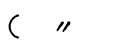 & 2) & 175 & 191 \\
\hline Vitamin A etc. & C $" \prime$ & 3) & 100 & 77 \\
\hline Vitamin B \& C & C " & 4) & 35 & 200 \\
\hline Minerals & 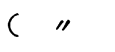 & 5) & 145 & 11.7 \\
\hline Fat & $C " \prime$ & $6)$ & 17 & 2 \\
\hline
\end{tabular}

of those operation by this picture.

Besides the mentioned diseases, there can be found many cases of cholelithiasis and Cholecyctic ascaridiasis in Japanese farm villages. Especially more cases are seen in this district. As for the cholelithiasis, more cases of bilirubin calculus are 
Table 3. Deaths from Malignant Neoplasms in Noto-District, Japan 1963

\begin{tabular}{|c|c|}
\hline Sites & Deaths \\
\hline Stomach & $160(51.0 \%)$ \\
\hline Lung \& Bronchus & $16(5.1 \%)$ \\
\hline Breast & $4(1.3 \%)$ \\
\hline Uterus & $17(5.4 \%)$ \\
\hline Leukemia group & $6(1.9 \%)$ \\
\hline Others & $111(35.3 \%)$ \\
\hline Total & $314(100 \%)$ \\
\hline
\end{tabular}

Table 4. Sites of Malignant Neoplasms in Patients

\begin{tabular}{|c|c|}
\hline Sites & $\left.\begin{array}{l}\text { Operable } \\
\text { Inoperable }\end{array}\right\} \cdots \cdots . . .$. Cases $\left(\varphi^{\prime}\right)$ \\
\hline Oesophagus & $\left.\begin{array}{l}0 \\
6\end{array}\right\} \cdots \cdots \cdots \cdots \cdots \cdots \cdots \cdots \cdots \cdots$ \\
\hline Stomach & $\left.\begin{array}{l}113 \\
122\end{array}\right\} \cdots \cdots \cdots \cdots \cdots \cdots \cdots \cdots \cdots+235 \quad(65.6 \%)$ \\
\hline Breast & $\left.\begin{array}{l}25 \\
10\end{array}\right\} \cdots \cdots \cdots \cdots \cdots \cdots \cdots \cdots \cdots$ \\
\hline Rectum & 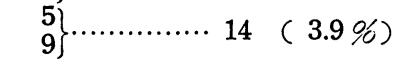 \\
\hline Uterus & $\left.\begin{array}{r}5 \\
15\end{array}\right\} \cdots \cdots \cdots \cdots \cdots \cdots \cdots \cdots \cdots \cdots$ \\
\hline Maxilla & $\left.\begin{array}{l}2 \\
4\end{array}\right\} \cdots \cdots \cdots \cdots \cdots \cdots \cdots \cdots \cdots$ \\
\hline Others & $\left.\begin{array}{l}28 \\
13\end{array}\right\} \cdots \cdots \cdots \cdots \cdots \cdots \cdots \cdots+41 \quad(11.4 \%)$ \\
\hline Total & $\left.\begin{array}{l}179 \\
179\end{array}\right\} \cdots \cdots \cdots \cdots \cdots \cdots \cdots \cdots(100.96)$ \\
\hline
\end{tabular}

seen in farm villages than in urban area. I will show you the samples chosen. from the operation examples which I have experienced at my hospital by this slide.

Finally, I emphasize the fact that under these circumstances, present farmers are getting to be healthy and endeavouring to establish their healthy, happy, comfortable and wealthy villages. 